\title{
Early Brown Rot Infections in Sweet Cherry Fruit Are Detected by Monilinia-Specific DNA Primers
}

\author{
H. Förster and J. E. Adaskaveg
}

Department of Plant Pathology, University of California, Riverside 92521.

Accepted for publication 1 November 1999.

\begin{abstract}
Förster, H., and Adaskaveg, J. E. 2000. Early brown rot infections in sweet cherry fruit are detected by Monilinia-specific DNA primers. Phytopathology 90:171-178.

Visible and nonvisible quiescent infections of immature and mature fruit are an integral component of the disease cycle of brown rot of sweet cherry in California. Detection of these infections is critical for developing efficient and efficacious fungicide management programs. The previously published DNA amplification primers $m f s 3$ and NS5 for the identification of Monilinia fructicola were very specific in amplifying DNA of M. fructicola only and not M. laxa. This primer set, however, only detected DNA from some of the California isolates of M. fructicola. This genetic diversity was supported by random amplified polymorphic DNA (RAPD) analysis. Using eight 10-mer primers, seven $M$. fructicola isolates from Cali-

M. fructicola, but not of M. laxa, using RAPD analysis could be indicative of genetic recombination within $M$. fructicola but not within M. laxa. To detect early brown rot infections in fruit, two primer sets that were developed from DNA sequences of either ribosomal DNA (MF5/ITS4/ITS3) or a RAPD fragment (X-09intF3/X-09R) specifically amplified DNA from isolates of M. fructicola and Monilinia species, respectively. No amplification products were present when using DNA from Botrytis cinerea or from other fungi commonly found on sweet cherry fruit. Primers X-09intF3 and $\mathrm{X}-09 \mathrm{R}$ were more sensitive and reliable for detecting small amounts of target DNA either extracted from conidia or from laboratory-inoculated cherry fruit with early brown rot infections that showed no visual symptoms or with visible quiescent infections. Furthermore, these primers also were effective for detecting visible quiescent infections in cherry fruit that were collected in the field.
\end{abstract} fornia were all identified as genetically distinct. Using the same primers, only one polymorphism was detected among seven isolates of M. laxa. The multiple genotypes identified within the small population sample of
Additional keywords: latent infections, polymerase chain reaction.
Quiescent fungal infections on sweet cherry (Prunus avium (L.) L.) can occur on green, immature, and mature fruit and they may be visible or nonvisible (1,7,31). A wide variety of fungi have been associated with these infections $(1,7)$. Among these fungi, Monilinia fructicola (G. Wint.) Honey and Botrytis cinerea Pers.:Fr. are the primary causes of pre- and postharvest fruit decays, known as brown rot and gray mold, respectively, in California (19). On maturing yellow-red sweet cherry varieties such as Rainier, Royal Ann, and Corum, visible quiescent infections caused by $M$. fructicola and $B$. cinerea are seen as tan spots that are surrounded by a reddish halo (1). In the past, the presence of quiescent infections in stone fruits has been substantiated by fungal isolations from surface-sterilized fruit or by dipping surface-sterilized fruit in a paraquat solution $(1,4,6,12,18)$. In paraquat-treated fruit, fungal infections are not affected by the herbicide, while plant tissue is killed. Thus, fungi in or on the fruit can grow saprophytically on the senescent or dead tissue, and they can be identified based on their cultural characteristics, spore ontogeny, and morphology. These detection procedures for quiescent infections involving direct fungal identification are quite time-consuming. In addition, these methods can be difficult to use on fungicide-treated fruit. Fungi may not show their typical morphology on treated fruit because many fungicides are systemic and will suppress growth (2) and sporulation (30).

There is a need for more rapid, but still accurate, methods for the early identification of fungal infections on sweet cherry and other stone fruits (Prunus spp.) to determine pre- and postharvest disease management practices, as well as postharvest shipping

Corresponding author: J. E. Adaskaveg; E-mail address: jim.adaskaveg@ucr.edu

Publication no. P-1999-1216-02R

(c) 2000 The American Phytopathological Society strategies for harvested crops. Many of the newer fungicides, such as the sterol biosynthesis inhibitors that are used for disease management, are mostly active against brown rot but not gray mold pathogens (J. E. Adaskaveg, unpublished data). Thus, pre- and postharvest fungicide treatments could be more accurately targeted if the disease potential was known. Postharvest shipping strategies for sweet cherry fruit in California could be more efficiently determined within the short time available for marketing before fruit rot or losses in quality occur. High-risk fruit lots could be directed to local markets, whereas low-risk lots would be suitable for longdistance transport or shipment into countries where postharvest treatments are not permitted. In addition, a disease detection system using molecular methods could be functional in certifying fruit for export before shipping to countries with quarantines.

The goal of our study was to detect early stages of brown rot infections of sweet cherry fruit using molecular methods that are rapid and specific for identification of Monilinia species. Detection methods that are based on the polymerase chain reaction (PCR) have been developed for many pathogens of plants (24) and other organisms (21), and these methods often assist rapid diagnosis. Recently, primers have been developed from the sequence of an intron within the small ribosomal DNA (rDNA) gene to distinguish $M$. fructicola from M. laxa and $M$. fructigena (11). These primers detected the pathogen in laboratory-inoculated plum fruit that showed signs of infections. Thus, an additional goal of our study was to compare the sensitivity of these primers with primers that we developed based on populations of Monilinia species from stone fruit crops in California. For this, the genetic diversity of $M$. fructicola and $M$. laxa was also evaluated to develop species- and genusspecific DNA primers to detect and identify these fungi in fruit infections. Results of this research will ultimately facilitate risk assessments, help in designing management programs, and optimize pesticide usage in the future. 


\section{MATERIALS AND METHODS}

Fungal isolates. Isolates of $M$. fructicola, M. laxa, B. cinerea, and other fungi from California that were used in this study are listed in Table 1. Isolates of $M$. fructicola were obtained from 16 orchards in 11 locations, and isolates of M. laxa were from 11 orchards in 7 locations throughout stone fruit production areas in California. Isolates were obtained from either blighted blossoms or decayed fruit. Isolate 81 was obtained from a single ascospore. Cultures were maintained on potato dextrose agar (PDA). For conidial production, M. fructicola was grown on clarified V8 agar (23) in the dark at $25^{\circ} \mathrm{C}$ for 8 to 10 days. Colony morphology was determined on PDA after 7 to 10 days, and cultures were designated M. fructicola or M. laxa following Batra (3).

Inoculation of cherry fruit with $\mathbf{M}$. fructicola in the laboratory. For production of nonvisible infections on mature, ripe Bing cherries, $20 \mu \mathrm{l}$ of a conidial suspension (30,000 conidia per $\mathrm{ml}$ ) of
M. fructicola (isolate 756) was pipetted onto each cherry fruit. These cherries came from relatively new orchards where brown rot historically had not been a problem. Fruit were incubated on wire racks in plastic boxes at $25^{\circ} \mathrm{C}$ with $>95 \%$ relative humidity. After 6,10 , or $18 \mathrm{~h}$, the droplets were dried using tissue paper. For each wetness period and sampling date, 18 fruit were inoculated. Samples for DNA extractions were taken 1, 24, 33, 48, and $72 \mathrm{~h}$ after inoculation. For this, cherry fruit were gently washed with $0.02 \%$ Tween 20 using a sponge and then rinsed for at least $1 \mathrm{~h}$ to remove any conidia adhering to the epicarp. Samples consisted of a 1 - to $2-\mathrm{cm}^{2} \times 1$ - to $2-\mathrm{mm}$ fruit surface, including the inoculation site, from a total of three fruit. Samples were kept frozen until DNA extractions were performed.

For production of visible quiescent infections on immature Bing cherries, detached fruit with no visible symptoms of quiescent infections were collected 2 to 3 weeks before harvest and inoculated with $20-\mu l$ droplets of water or a conidial suspension of M. fructi-

TABLE 1. Fungi, isolation hosts, and collection locations of fungal isolates used in this study and specificity of DNA primers used in polymerase chain reaction amplifications to Monilinia fructicola, M. laxa, Botrytis cinerea, and other fungi associated with sweet cherry in California

\begin{tabular}{|c|c|c|c|c|c|c|c|}
\hline \multirow{2}{*}{$\begin{array}{l}\text { Isolate } \\
\text { no. }\end{array}$} & \multirow[b]{2}{*}{ Fungal species } & \multicolumn{2}{|c|}{ Isolation host } & \multirow{2}{*}{$\begin{array}{l}\text { Collection } \\
\text { location }^{\mathrm{a}}\end{array}$} & \multicolumn{3}{|c|}{ Specificity of DNA primers } \\
\hline & & Scientific name & Common name & & $m f s 3 / \mathrm{NS} 5$ & X-09intF3/X-09R & MF5/ITS3/ITS4 \\
\hline 49 & Monilinia fructicola & Prunus sp. & $\ldots$ & $\ldots$ & - & + & + \\
\hline 50 & M. fructicola & P. persica & Peach & Cortez, CA & - & + & + \\
\hline 66 & M. fructicola & P. persica & Peach & Modesto, CA & + & + & + \\
\hline 67 & M. fructicola & P. persica & Peach & Lockeford, CA & + & + & + \\
\hline 71 & M. fructicola & Malus sp. & Apple & Placerville, CA & - & + & + \\
\hline 74 & M. fructicola & P. persica & Peach & Lockeford, CA & - & + & + \\
\hline 79 & M. fructicola & P. persica & Peach & Lockeford, CA & + & + & + \\
\hline 80 & M. fructicola & $P$. salicina & Plum & Parlier, CA & - & + & + \\
\hline 81 & M. fructicola & P. persica & Peach & Linden, CA & - & + & + \\
\hline 83 & M. fructicola & P. persica & Peach & Lockeford, CA & - & + & + \\
\hline 85 & M. fructicola & P. persica var. nucipersica & Nectarine & Fresno, CA & - & + & + \\
\hline 86 & M. fructicola & P. salicina & Plum & Parlier, CA & - & + & + \\
\hline $94-6$ & M. fructicola & P. avium & Sweet cherry & Stockton, CA & $\mathrm{ND}^{\mathrm{b}}$ & ND & ND \\
\hline 124 & M. fructicola & P. persica & Peach & Lockeford, CA & - & + & + \\
\hline 142 & M. fructicola & P. avium & Sweet cherry & Lodi, CA & - & + & + \\
\hline 153 & M. fructicola & P. avium & Sweet cherry & Lodi, CA & + & + & + \\
\hline 159 & M. fructicola & P. avium & Sweet cherry & Lodi, CA & - & + & + \\
\hline 756 & M. fructicola & $P$. avium & Sweet cherry & Bellota, CA & + & + & + \\
\hline 1517 & M. fructicola & P. persica var. nucipersica & Nectarine & Fresno, CA & + & + & + \\
\hline 1518 & M. fructicola & $P$. salicina & Plum & Fresno, CA & + & + & + \\
\hline 1974 & M. fructicola & $P$. salicina $\times P$. armeniaca & Pluot & Dinuba, CA & - & + & + \\
\hline 1975 & M. fructicola & P. persica & Peach & Dinuba, CA & + & + & + \\
\hline 10 & M. laxa & P. domestica & Prune & Marysville, CA & - & + & - \\
\hline 17 & M. laxa & P. domestica & Prune & Marysville, CA & - & + & - \\
\hline 25 & M. laxa & P. armeniaca & Apricot & Davis, CA & - & + & - \\
\hline 31 & M. laxa & Cydonia oblonga & Quince & Davis, CA & - & + & - \\
\hline 55 & M. laxa & P. dulcis & Almond & Merced, CA & - & + & - \\
\hline 66 & M. laxa & P. dulcis & Almond & Merced, CA & - & + & - \\
\hline 77 & M. laxa & $P$. persica & Peach & Davis, CA & - & + & - \\
\hline 125 & M. laxa & P. armeniaca & Apricot & Davis, CA & - & + & - \\
\hline 126 & M. laxa & P. dulcis & Almond & Davis, CA & - & + & - \\
\hline 130 & M. laxa & P. dulcis & Almond & Butte, CA & - & + & - \\
\hline 1464 & M. laxa & P. dulcis & Almond & Modesto, CA & - & + & - \\
\hline 1723 & M. laxa & P. dulcis & Almond & Colusa, CA & - & + & - \\
\hline 1718 & M. laxa & P. dulcis & Almond & Butte, CA & - & + & - \\
\hline 1724 & M. laxa & P. dulcis & Almond & Colusa, CA & - & + & - \\
\hline 1735 & M. laxa & P. dulcis & Almond & Colusa, CA & - & + & - \\
\hline 51 & Botrytis cinerea & P. domestica & Prune & Davis, CA & - & - & - \\
\hline 52 & B. cinerea & P. avium & Sweet cherry & Stockton, CA & - & - & - \\
\hline 53 & B. cinerea & P. avium & Sweet cherry & Stockton, CA & - & - & - \\
\hline 89 & B. cinerea & P. avium & Sweet cherry & Bellota, CA & - & - & - \\
\hline 91 & B. cinerea & P. avium & Sweet cherry & Lodi, CA & - & - & - \\
\hline 104 & B. cinerea & Fragaria $\times$ ananassa & Strawberry & Santa Barbara, CA & - & - & - \\
\hline 109 & B. cinerea & P. avium & Sweet cherry & Lodi, CA & - & - & - \\
\hline 148 & B. cinerea & P. avium & Sweet cherry & Stockton, CA & - & - & - \\
\hline 100 & Alternaria alternata & Prunus sp. & $\ldots$ & $\ldots$ & ND & - & - \\
\hline 161 & Cladosporium sp. & $P$. avium & Sweet cherry & Lodi, CA & ND & - & - \\
\hline 172 & C. cladosporioides & P. avium & Sweet cherry & Lodi, CA & ND & - & - \\
\hline 178 & Sclerotinia sclerotiorum & P. avium & Sweet cherry & Lodi, CA & ND & - & - \\
\hline 1218 & Epicoccum nigrum & P. avium & Sweet cherry & Riverside, CA & ND & - & - \\
\hline
\end{tabular}

a Isolate numbers 80 and $86 ; 67,74,79,83$, and $124 ; 10$ and $17 ; 31$ and 61 ; and 1,724 and 1,735 were from the same orchard in each location.

${ }^{\mathrm{b}} \mathrm{ND}=$ not determined. 
cola (isolate 756) (30,000 spores per $\mathrm{ml})$. Inoculated fruit were incubated in the dark at $20^{\circ} \mathrm{C}$ with $>95 \%$ relative humidity. The droplets were carefully dried using tissue paper after $9 \mathrm{~h}$, and fruit were air-dried for $30 \mathrm{~min}$. Fruit then continued to be incubated at the same temperature and relative humidity for up to 10 days. Visible quiescent infections were defined as reddish circular halos with tan centers. Samples for DNA extractions were taken from fruit with visible quiescent infections as described above.

DNA extraction from fungal tissue and cherry fruit. Fungal DNA was extracted by a modified procedure (17) of Raeder and Broda (22). For DNA extraction of cherry epicarp tissue that was sampled as described above, tissue was homogenized in microfuge tubes using a pellet pestle. After adding $700 \mu \mathrm{l}$ of extraction buffer (312 mM EDTA, pH 8; 10 mM Tris-HCl, pH 8; 1\% sodium lauryl sulfate; and $1 \%$ polyvinylpolypyrrolidone) (26), the suspension was incubated at $90^{\circ} \mathrm{C}$ for $30 \mathrm{~min}$. After two phenol-chloroform extractions, 0.75 volume of distilled water was added to the aqueous phase. For DNA precipitation, 0.1 volume of $7.5 \mathrm{M}$ ammonium acetate and 0.7 volume of isopropanol were added. After centrifugation at $12,000 \times g$ for $15 \mathrm{~min}$, the pellet was washed with $95 \%$ ethanol, dried, and resuspended in $100 \mu \mathrm{l}$ of sterile distilled water. The DNA extract was additionally purified using Geneclean (Bio 101, Inc., La Jolla, CA) according to the manufacturer's protocol.

Development of species-specific primers for $M$. fructicola from rDNA internal transcribed spacer (ITS) I sequence data. Primer selection (ITS1 and ITS2) and PCR amplification protocols for the ITS I region of rDNA were based on methods by White et al. (29). For sequencing, PCR products of $M$. fructicola (isolates 756 and 94-6) were column-purified using Wizard PCR Preps (Promega Corp., Madison, WI). Double-stranded DNA templates were sequenced on both strands using the fmol DNA Sequencing System (Promega Corp.) and ${ }^{33} \mathrm{P}$ end-labeled primers ITS1 and ITS2. A 5' primer (MF5) was constructed from the part of the ITS I region that had the most mismatches when compared with ITS I sequences of $M$. laxa and $B$. cinerea, using the computer program OLIGO version 4.0 (W. Rychlik, Lifescience Software Resources, Long Lake, MN). Primers were synthesized by Integrated DNA Technologies (Coralville, IA) and were then tested under selected amplification conditions (different annealing temperatures and cycling times) using DNA from pure fungal cultures as template DNA and using the universal primer ITS4 as the 3' primer. The universal primer ITS3 was included as an internal standard primer. Therefore, the species-specific primer MF5, together with ITS4, amplified a species-specific DNA fragment, whereas ITS3 and ITS4 amplified a nonspecific DNA fragment with all fungi tested. The latter DNA product served as an internal standard to show that the amplification conditions were satisfactory.

DNA amplifications for random amplified polymorphic DNA (RAPD) analysis. Amplification reactions were carried out in volumes of $25 \mu \mathrm{l}$ containing $1 \mu \mathrm{l}$ of DNA extract, $14.3 \mu \mathrm{l}$ of sterile dis-

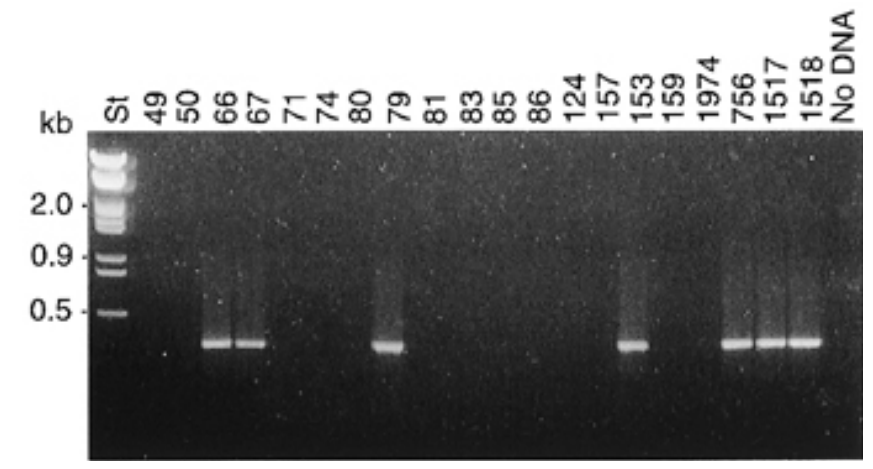

Fig. 1. Polymerase chain reaction amplification using DNA from isolates of Monilinia fructicola from California and primers $m f s 3$ and NS5. The annealing temperature for the reaction was $58^{\circ} \mathrm{C}$. Lambda phage DNA digested with HindIII and EcoRI was used as a DNA size standard (St).

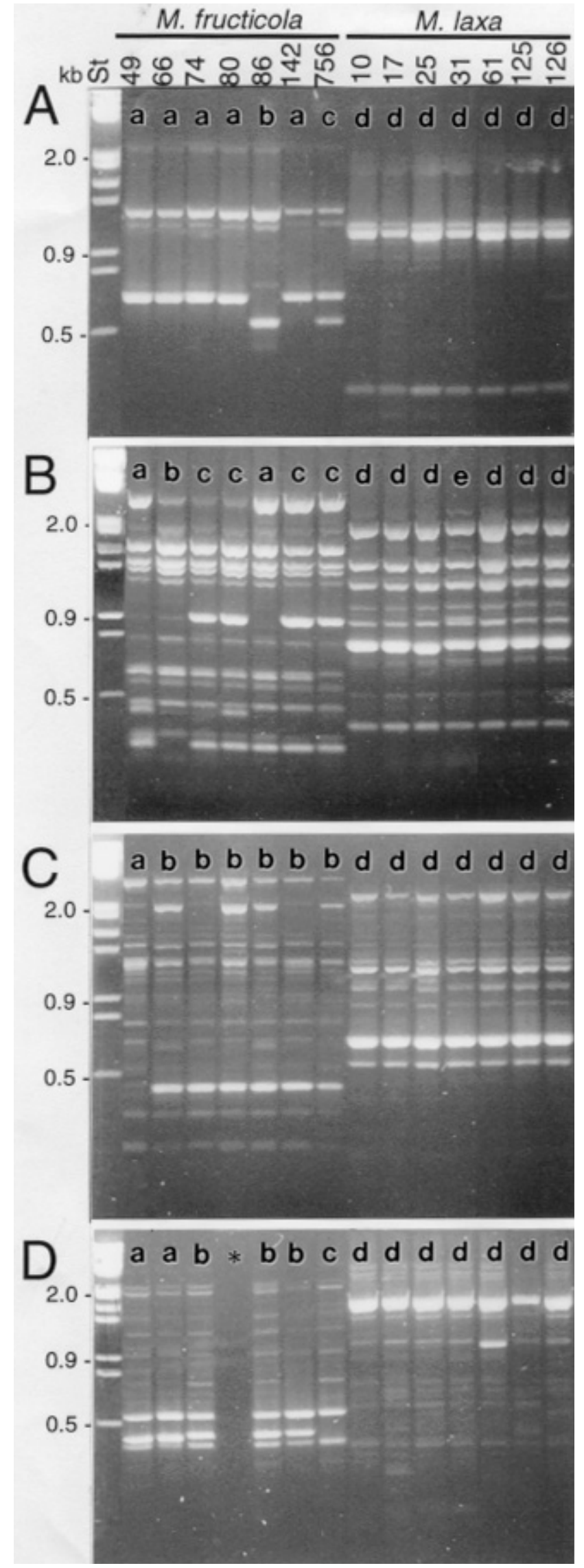

Fig. 2. RAPD analysis of seven California isolates each of Monilinia fructicola and $M$. laxa using random 10-mer primers A, OPN-01; B, OPN-02; C, OPR-02; and D, OPR-08 (isolate 80 was not used here). The annealing temperature for these reactions was $35^{\circ} \mathrm{C}$. Lambda phage DNA digested with HindIII and EcoRI was used as a DNA size standard (St). Banding patterns that were scored as different were given different alphabetical designations. $*=$ No DNA applied to lane. 
tilled water, $2.5 \mu \mathrm{l}$ of $10 \times$ reaction buffer $(500 \mathrm{mM} \mathrm{KCl} ; 100 \mathrm{mM}$ Tris-HCl, pH 8.3; and 1\% Triton X-100), $2 \mu$ of dNTP stock ( $2.5 \mathrm{mM}$ each dNTP), $4 \mu \mathrm{l}$ of $\mathrm{MgCl}_{2}(10 \mathrm{mM}), 1 \mu \mathrm{l}$ of $10 \mu \mathrm{M}$ primer (Operon Technologies Inc., Alameda, CA), and 1 unit of Taq DNA polymerase (Promega Corp.). Primers OPN-01, OPN-02, OPN-03, OPN-05, OPR-02, OPR-08, OPX-03, and OPX-09 were used for evaluating the genetic diversity among $M$. fructicola and $M$. laxa. Amplifications were performed in a PTC-100 Programmable Thermal Controller (MJ Research, Inc., Watertown, MA) using the following conditions: initial denaturation for $30 \mathrm{~s}$ at $94^{\circ} \mathrm{C} ; 35$ cycles of $30 \mathrm{~s}$ of denaturation at $94^{\circ} \mathrm{C}, 30 \mathrm{~s}$ of annealing at $35^{\circ} \mathrm{C}$, and $1 \mathrm{~min}$ of extension at $72^{\circ} \mathrm{C}$; this was followed by a final extension for $7 \mathrm{~min}$ at $72^{\circ} \mathrm{C}$. Reaction products were resolved by electrophoresis in $1.5 \%$ agarose (Promega Corp.) using $0.5 \times$ Tris-borate-EDTA buffer at 10 to $15 \mathrm{~V} / \mathrm{cm}$. Banding patterns were compared among the isolates for each DNA primer evaluated. They were scored as different based on the presence or absence of DNA amplification products of high intensity less than $1 \mathrm{~kb}$ in size and were given alphabetical designations for each pattern.

Development of Monilinia-specific primers from RAPD. Another set of specific primers was designed from RAPD. Polymorphic DNA was identified by evaluating 37 random primers (Operon Technologies, Inc.) in PCR amplifications (described above). Using primer OPX-09, a DNA fragment that was absent in $B$. cinerea and that was of high band intensity in isolates of $M$. fructicola and M. laxa was cloned into a vector using the pGEM-T Easy system (Promega Corp.). From both ends of this fragment, 90 to 100 nucleotides were sequenced with the fmol DNA Sequencing System. From these sequences, primers were designed using the computer program OLIGO and then tested under selected amplification conditions.

DNA amplifications using Monilinia-specific primers. Amplification reactions were carried out in volumes of $25 \mu \mathrm{l}$ containing $1 \mu \mathrm{l}$ of DNA extract, $16 \mathrm{ml}$ of sterile distilled water, $2.5 \mu \mathrm{l}$ of $10 \times$ reaction buffer $(500 \mathrm{mM} \mathrm{KCl} ; 100 \mathrm{mM}$ Tris- $\mathrm{HCl}, \mathrm{pH} 8.3$; and $1 \%$ Triton X-100), $0.25 \mu \mathrm{l}$ of bovine serum albumin $(10 \mathrm{mg} / \mathrm{ml}), 2 \mu \mathrm{l}$ of dNTP stock (2.5 mM each dNTP), $2 \mu \mathrm{l}$ of $25 \mathrm{mM} \mathrm{MgCl}_{2}, 1 \mu \mathrm{l}$ of each primer $(10 \mu \mathrm{M}$ except ITS3, which was $1 \mu \mathrm{M})$, and 0.8 units of Taq DNA polymerase (Promega Corp.). Amplifications were performed using the following conditions: initial denaturation for $30 \mathrm{~s}$ at $94^{\circ} \mathrm{C} ; 35$ cycles of $30 \mathrm{~s}$ of denaturation at $94^{\circ} \mathrm{C}, 30 \mathrm{~s}$ of annealing at $72^{\circ} \mathrm{C}$, and $1 \mathrm{~min}$ of extension at $72^{\circ} \mathrm{C}$; this was followed by a final extension for $5 \mathrm{~min}$ at $72^{\circ} \mathrm{C}$. Annealing temperatures were $58^{\circ} \mathrm{C}$ for primers $m f s 3$ and NS5; $59^{\circ} \mathrm{C}$ for primers MF5, ITS4, and ITS3; and $55^{\circ} \mathrm{C}$ for primers X-09intF3 and X-09R.

Sensitivity of Monilinia-specific primers. The detection limits of the primer sets were evaluated by performing PCR using DNA that was obtained from known amounts of fungal tissue. For this, DNA was extracted from aliquots of conidial suspensions containing between $10^{3}$ and $10^{5}$ conidia of $M$. fructicola per $\mathrm{ml}$. One microliter of the DNA extract was then used in PCR amplifications. Sensitivity of primers was also evaluated using known amounts of fungal DNA in the presence of cherry fruit DNA. For this, selected amounts of conidia were added to cherry tissue (1- to 2- $\mathrm{cm}^{2} \times$ 1- to 2-mm fruit surface), DNA extractions were done as described above, and $1 \mu \mathrm{l}$ of the extract (containing DNA from 20 to 1,000 conidia of M. fructicola) was used in PCR.
Field collection of cherry fruit with visible quiescent infections. During the 1998 growing season, fruit of the yellow-red cherry varieties Rainier, Corum, and Royal Ann showing visible quiescent infections were collected from a commercial orchard in Bellota, CA, where no fungicides were applied during the growing season. Immature, yellow-pink fruit showing reddish circular halos with tan centers (approximately 1 to $2 \mathrm{~mm}$ in diameter) were collected 2 to 3 weeks before harvest.

\section{RESULTS}

Evaluation of primers $m f s 3$ and NS5 for detecting $M$. fructicola DNA. DNA from 21 isolates of $M$. fructicola and 15 isolates of $M$. laxa originating from different stone fruit crops in California were used in PCR amplifications using primers $m f s 3$ and NS5 that were developed from rDNA intron sequences of $M$. fructicola by Fulton and Brown (11). Only seven of the M. fructicola isolates produced a band of the expected size using these primers, while no band was present in any of the $M$. laxa and B. cinerea isolates (Fig. 1; Table 1).

Genetic diversity among M. fructicola and M. laxa in California. The genetic variability among seven isolates of $M$. fructicola (isolates 49, 66, 74, 80, 86, 142, and 756) and seven isolates of M. laxa (isolates 10, 20, 25, 31, 61, 125, and 126) was evaluated in a RAPD analysis using eight random 10-mer primers. The analysis revealed that all seven $M$. fructicola isolates were distinct. RAPD banding patterns generated using a specific random primer generally differed in the presence or absence of one or two bands, while the remaining bands were identical among isolates (Fig. 2A to D). Genotypes were assigned based on banding pattern designations. Thus, genotypes for M. fructicola isolates 49, 66, 74, $80,86,142$, and 756 were $a a a a, a b b a, a c b b, a c b a, b a b b, a c b b$, and $c c b c$, respectively, using primers OPN-01, OPN-02, OPR-02,

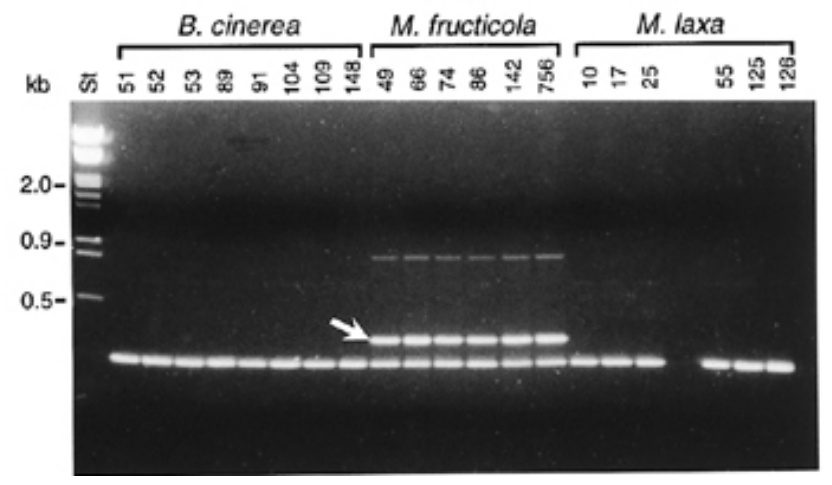

Fig. 4. Specificity of primers developed from ribosomal DNA (rDNA) for distinguishing between Monilinia fructicola, M. laxa, and Botrytis cinerea. Specific polymerase chain reaction amplification of $M$. fructicola DNA using primer MF5 that was derived from rDNA sequence data together with the universal primers ITS 3 and ITS4. The arrow indicates the M. fructicola-specific DNA band, which is not present using DNA of B. cinerea or isolates of M. laxa as template DNA. The nonspecific DNA band below is an ITS3-ITS4 fragment of the internal transcribed spacer (ITS) region that served as an internal standard. The annealing temperature for the reaction was $61^{\circ} \mathrm{C}$. Lambda phage DNA digested with HindIII and EcoRI was used as a DNA size standard (St).

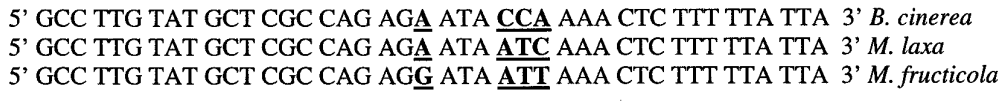

GCT CGC CAG AG $\underline{\text { ATA }} \underline{\mathbf{A T T}}$

MF5 (18mer)

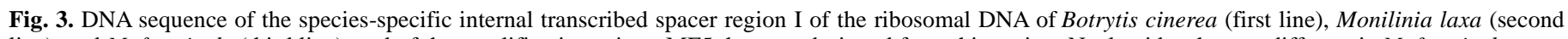

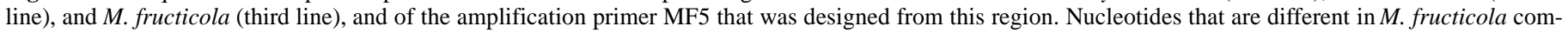
pared with B. cinerea and $M$. laxa are underlined and in bold. 
and OPR-08. Additional polymorphisms were detected using primers OPN-03, OPX-03, and OPX-09; whereas all isolates were identified as monomorphic when using primer OPN-05. Overall, banding patterns were quite similar among the isolates. Banding patterns of the seven isolates of $M$. laxa were almost identical (genotype $d d d d$ ) for all eight primers (Fig. 2A to D, four primers shown). Only one isolate (isolate 31) differed in one band (a double band at approximately $0.9 \mathrm{~kb}$ ) using primer OPN-02. This genotype was designated $d e d d$.

Evaluation of primers developed from ribosomal ITS I sequence data or from RAPD of M. fructicola and evaluation for specificity using DNA from pure fungal cultures. The ITS I sequences obtained for two isolates of $M$. fructicola from two cherry orchards in California were identical. Primer MF5 was designed from the $3^{\prime}$ end of the ITS I region where four mismatches were found as compared with sequences of $M$. laxa and B. cinerea (Fig. 3). Using this primer together with primers ITS3 and ITS4 at annealing temperatures between 59 to $61^{\circ} \mathrm{C}$, two DNA bands were generated using $M$. fructicola DNA from pure cultures (Fig. 4). The first band was approximately $440 \mathrm{bp}$ in size and was $M$. fructicolaspecific, being present in all $21 \mathrm{M}$. fructicola isolates evaluated. The second band was a nonspecific ITS3-ITS4 fragment approximately $345 \mathrm{bp}$ in size, identified as present when using DNA from all fungal isolates including M. laxa, B. cinerea (Fig. 4), and species of $A l$ ternaria, Cladosporium, Sclerotinia, or Epicoccum (data not shown).

For primer development from RAPD, polymorphic DNA of $M$. fructicola was identified following PCR using 37 random 10-mer

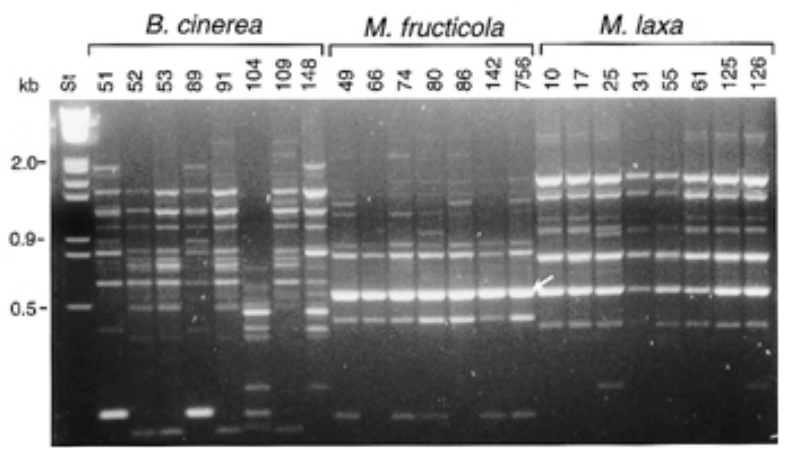

Fig. 5. Random amplified polymorphic DNA amplification patterns for isolates of Botrytis cinerea, Monilinia fructicola, and $M$. laxa using random primer OPX-09. The arrow indicates the Monilinia-specific DNA band that was cloned, sequenced, and used for the development of brown rot detection primers. The annealing temperature for these reactions was $35^{\circ} \mathrm{C}$. Lambda phage DNA digested with HindIII and EcoRI was used as a DNA size standard (St).

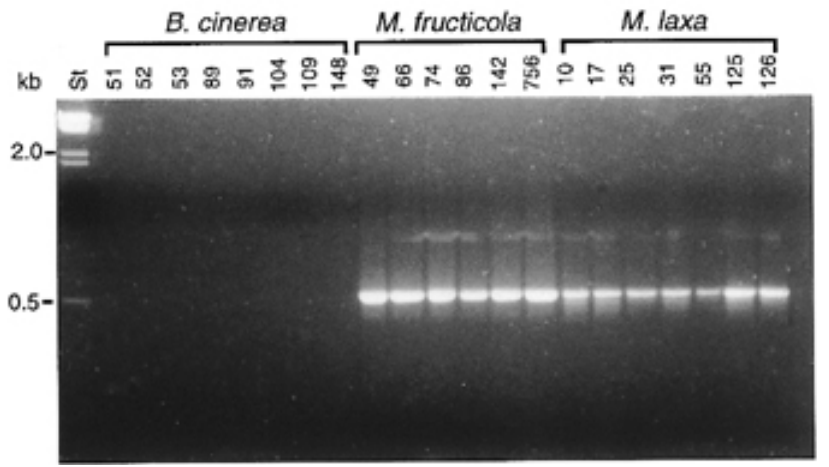

Fig. 6. Specificity of primers developed from random amplified polymorphic DNA (RAPD) for distinguishing between Monilinia fructicola, M. laxa, and Botrytis cinerea. Specific polymerase chain reaction amplification of Monilinia DNA using primers $\mathrm{X}-09 \mathrm{intF} 3$ and $\mathrm{X}-09 \mathrm{R}$ that were derived from a RAPD fragment that was absent in $B$. cinerea. The annealing temperature for this reaction was $52^{\circ} \mathrm{C}$. Lambda phage DNA digested with HindIII and EcoRI was used as a DNA size standard (St). primers and comparing DNA banding patterns using $M$. fructicola, $M$. laxa, or B. cinerea DNA as the template. Using primer OPX-O9, one DNA band of high intensity was identified as present in all isolates of M. fructicola, but of lower intensity in M. laxa and absent in B. cinerea (Fig. 5, arrow). After sequencing both ends of this Monilinia-specific DNA fragment, primers were designed and evaluated for their specificity. Primers X-09intF3 (GATTCAGCTTGTGCGTAT) and X-09R (GGTCTGGTTGGTATACC) generated a Monilinia-specific DNA band approximately 500 bp in size with $M$. fructicola and M. laxa (Fig. 6). This primer set was very specific in excluding B. cinerea (Fig. 6) and isolates of species of Alternaria, Cladosporium, Sclerotinia, or Epicoccum (data not shown) and proved to be consistent in many amplification reactions at annealing temperatures between 52 and $55^{\circ} \mathrm{C}$.

Evaluation of primer sensitivity. Detection limits of the Monilinia-specific primers were evaluated by extracting DNA from known quantities of fungal conidia. In amplifications using primer MF5, which was developed from rDNA, and the nonspecific primers ITS 3 and ITS4, the detection limit was 20 to 100 conidia per

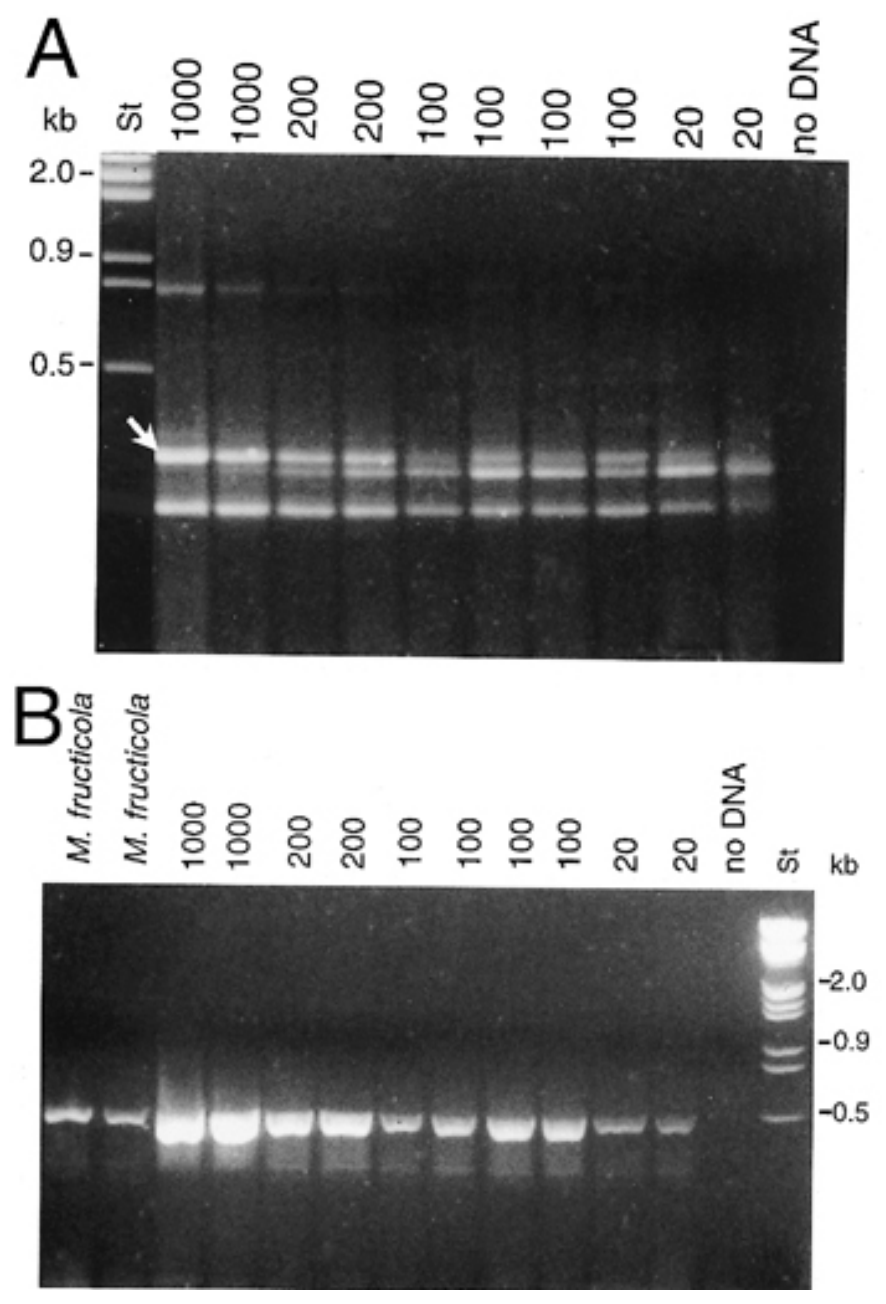

Fig. 7. Sensitivity of the designed primers in detecting Monilinia fructicola in cherry tissue. Selected amounts of $M$. fructicola conidia were added to cherry tissue, DNA was extracted, and polymerase chain reaction (PCR) amplifications were carried out. The numbers above the lanes indicate the calculated numbers of $M$. fructicola conidia used in DNA preparations in each PCR. Lambda phage DNA digested with HindIII and EcoRI was used as a DNA size standard (St). A, Sensitivity using primers MF5 (internal transcribed spacer [ITS] derived), ITS3, and ITS4 (annealing temperature $59^{\circ} \mathrm{C}$ ). The arrow indicates the $M$. fructicola-specific DNA band. Immediately below this band is a ribosomal DNA (rDNA) fragment amplified from cherry DNA, and the smallest DNA fragment represents a nonspecific Monilinia DNA fragment from the ITS region of rDNA. B, Sensitivity using primers X-09intF3 and X-09R (random amplified polymorphic DNA derived) (annealing temperature $55^{\circ} \mathrm{C}$ ). DNA from 20 conidia could be detected in cherry tissue. 
PCR. With primers X-09intF3 and X-09R, which were developed from RAPD, DNA from 20 conidia per PCR could be detected consistently. When known quantities of fungal conidia were added to cherry fruit tissue, followed by DNA extraction, similar sensitivities were obtained for both primer combinations (Fig. 7A and B). Using primers MF5, ITS3, and ITS4 in these reactions with DNA from fungal conidia and cherry fruit tissue, an additional DNA fragment was amplified from cherry DNA (Fig. 5A). This DNA fragment was approximately $410 \mathrm{bp}$ in size and migrated just below the $M$. fructicola-specific fragment in agarose gels (Fig. 7A).

Primer evaluation for detecting $M$. fructicola in laboratoryinoculated cherry fruit. Using primers MF5, ITS3, and ITS4, the detection of $M$. fructicola in laboratory-inoculated Bing cherries with no visible symptoms depended on the wetness period after inoculation and the total incubation time before sampling (Fig. 8A). After a 6-h wetness period and 24 to $72 \mathrm{~h}$ of incubation, a faint $M$. fructicola-specific DNA band was evident for $10 \%$ of the fruit evaluated. After a 10-h wetness period and $24 \mathrm{~h}$ of incubation, the fungus could be detected in approximately $50 \%$ of the cherry fruit evaluated. In samples taken $48 \mathrm{~h}$ after inoculation $(6,10$, or $18 \mathrm{~h}$ of wetness) and incubation $\left(25^{\circ} \mathrm{C}\right)$, the fungus was detected in $80 \%$ of the cherry fruit. After an 18 -h wetness period, M. fructicolaspecific bands were present in $85 \%$ of the cherries that were sampled $24 \mathrm{~h}$ after inoculation. In contrast, using the primers developed from the OPX-09 RAPD fragment, the fungus could already be detected after a 6-h wetness period when samples were taken $24 \mathrm{~h}$ after inocu-
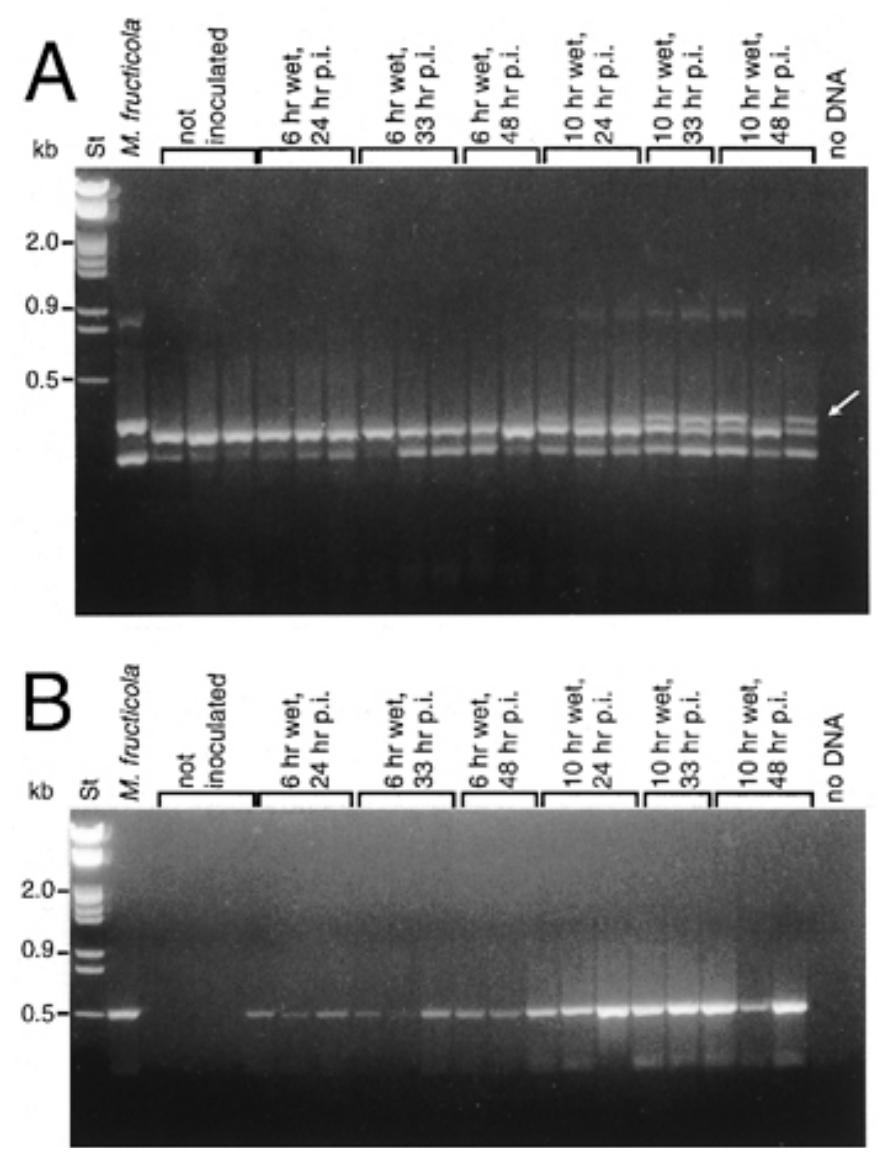

Fig. 8. Detection of nonvisible Monilinia fructicola infections on laboratoryinoculated Bing cherry. Cherry fruit was inoculated with $20-\mu 1$ droplets containing 600 conidia of the fungus. The droplets were dried after 6 or $10 \mathrm{~h}$, and samples were taken 24, 33, or $48 \mathrm{~h}$ after inoculation. A, Detection of $M$. fructicola using primers MF5, ITS3, and ITS4 (annealing temperature $59^{\circ} \mathrm{C}$ ). The arrow indicates the $M$. fructicola-specific DNA band. B, Detection of $M$. fructicola using primers X-09intF3 and X-09R (annealing temperature $55^{\circ} \mathrm{C}$ ). Lambda phage DNA digested with HindIII and EcoRI was used as a DNA size standard (St). lation (Fig. 8B). No DNA bands were present with tissue samples taken $1 \mathrm{~h}$ after a 6-h wetness period.

After a 9-h wetness period, visible quiescent infections were produced in $60 \%$ of the fruit in laboratory inoculations of immature Bing cherry fruit. These quiescent infections were visible as reddish circular halos with tan centers and did not develop into active decay after prolonged incubation. Using both primers sets, either designed from rDNA or from RAPD, specific DNA bands were identified as present when using DNA extracts from fruit tissue with visible quiescent infections (data not shown).

Primer evaluation for detecting $M$. fructicola in naturally infected cherry fruit. Fruit of the yellow-red cherry varieties Rainier, Corum, and Royal Ann showing visible quiescent infections were collected during the 1998 cherry season. After DNA extraction and PCR amplification using primers X-09intF3 and X-09R, the Monilinia-specific DNA band was detected in all fruit with visible quiescent infections, whereas symptomless fruit (Bing cherry fruit from the low-disease 1997 season were used) were all negative (Fig. 9). Using primers MF5, ITS3, and ITS4, M. fructicola only could be detected in approximately $20 \%$ of the fruit with quiescent infections.

\section{DISCUSSION}

We utilized PCR technology to develop a rapid method for the detection of early and quiescent brown rot infections of sweet cherry fruit. PCR amplification primers for the specific detection of organisms frequently are obtained from rDNA sequences, because rDNA is found in many copies in the genome, making detection systems very sensitive compared with primers designed from singlecopy DNA. For the specific detection of M. fructicola, we evaluated rDNA intron primers that were designed by Fulton and Brown (11) and that distinguished all $16 \mathrm{M}$. fructicola isolates (from a worldwide collection) from $M$. laxa and $M$. fructigena (11). The rDNA intron was also shown to be present in 32 isolates of $M$. fructicola, while it was absent in 8 isolates of $M$. laxa from cherry fruit in Michigan (25). Interestingly, in our study, these intron primers generated a band with only 8 of the $21 \mathrm{M}$. fructicola isolates from California evaluated. No DNA band was present in any of the $15 \mathrm{M}$. laxa isolates. These isolates of Monilinia were collected from a range of hosts in California that included apricot, almond, sweet cherry, peach, nectarine, plum, pluot, and prune to provide a wide range of genetic diversity that might occur within the two fun-

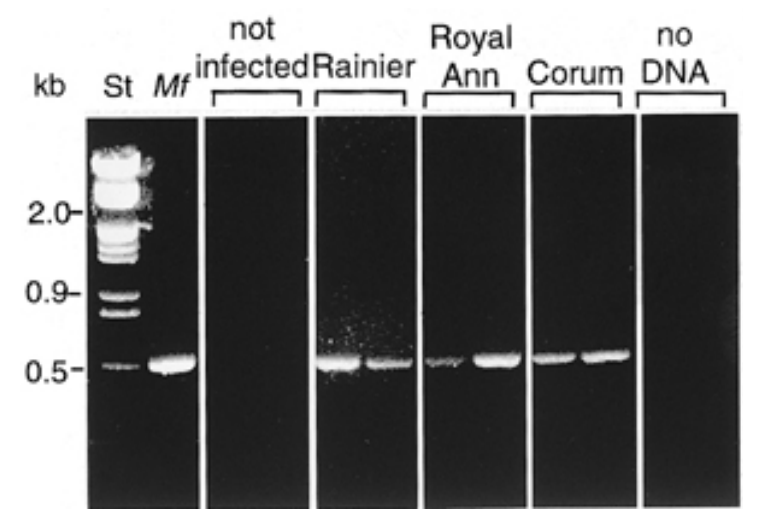

Fig. 9. Detection of natural visible quiescent infections of Monilinia fructicola on the yellow-red cherry varieties Rainier, Royal Ann, and Corum using primers X-09intF3 and X-09R (annealing temperature $55^{\circ} \mathrm{C}$ ). Noninfected Bing cherries from the 1997 field season that had a very low disease incidence served as a negative control. In each of two lanes for each variety, polymerase chain reaction amplifications were done using extracts of epicarp tissue from eight naturally occurring, visible quiescent infections excised from fruit collected in the field. Bands indicate the presence of DNA of Monilinia spp. Lambda phage DNA digested with HindIII and EcoRI was used as a DNA size standard (St). 
gal species. Consequently, isolates of M. fructicola in California are distinct, and a detailed analysis of the worldwide genetic variability of the species could be a goal for future studies. The genetic variability among the California isolates of $M$. fructicola, as indicated by the presence or absence of the rDNA intron, was further supported by a RAPD analysis using a subset of seven isolates. All seven isolates were distinct, differing in at least one banding pattern generated using a specific primer. Overall, however, banding patterns among the seven isolates were similar. Previously, when using arbitrarily primed PCR analysis, very little genetic variability was found among 28 isolates of $M$. fructicola that were obtained from cherry in four locations in Michigan (25). In contrast to $M$. fructicola, very little genetic variability was detected among California isolates of M. laxa in our study. A more extensive study needs be done to determine if this difference between the two species of Monilinia reflects their reproductive patterns. The apothecial or sexual stage of M. fructicola, but not of M. laxa, is commonly found in California (19). Although the former fungus is considered homothallic based on observations that single-ascospore cultures could produce apothecia (13), outcrossing is considered to occur based on segregation of phenotypes in ascospore progenies $(10,27)$. The results of our RAPD study, with the number of genotypes identified in $M$. fructicola, could be indicative of common recombination or outcrossing among isolates of M. fructicola in California, but not in M. laxa. Molecular analyses of single-ascospore progenies need to be conducted to further characterize the role of outcrossing in populations of M. fructicola in California. Faretra et al. (8), studying another member of the family Sclerotiniaceae, indicated that Botryotinia fuckeliana (Botrytis cinerea) is mostly heterothallic, with some homothallic isolates among ascospore progeny. In our study, RAPD analysis of B. cinerea (Fig. 5) (H. Förster and J. E. Adaskaveg, unpublished data) also resulted in multiple patterns, indicative of a heterothallic fungus with genetic recombination commonly occurring.

For the specific detection of all California M. fructicola isolates, we developed two sets of PCR amplification primers, one from rDNA and one from RAPD. The DNA sequences of the ITS I region of rDNA that we obtained for two California isolates of $M$. fructicola were identical for both isolates, and they were also identical to the sequence for $M$. fructicola that was published by Carbone and Kohn (5). We designed and evaluated a primer (MF5) from a region of the ITS I of $M$. fructicola where four mismatches were present compared with the published sequences of $M$. laxa and $B$. cinerea $(5,14,15)$. In addition, we developed amplification primers from a polymorphic RAPD fragment (primers X-09intF3 and X-09R). Whereas both MF5 and the OPX-09 primers specifically amplified Monilinia DNA, only the MF5 primer was able to discriminate between $M$. fructicola and M. laxa. This, however, will not be a drawback for the OPX-09 primers, because under natural conditions $M$. laxa, is rarely a fruit pathogen of sweet cherry in California $(3,20)$. Sensitivity in detecting small amounts of DNA was similar for the two types of primers; however, the OPX-09 primers were more reliable in detecting small amounts of DNA from fungal conidia or when known amounts of fungal conidia were added to cherry fruit tissue before DNA extraction. Furthermore, using DNA from laboratory-inoculated and naturally infected cherry fruit, the OPX-09 primers were much more sensitive compared with primer MF5. The high sensitivity of the RAPD-derived primers indicated that the OPX-09 DNA fragment lies within a high-copy-number region of the fungal genome.

In laboratory studies determining the time limits of detection after inoculation, Monilinia-specific DNA bands were identified as present $24 \mathrm{~h}$ after inoculation when using a 6-h wetness period. Because no DNA bands were present with tissue samples that were taken $1 \mathrm{~h}$ after a 6-h wetness period following inoculation, most fungal conidia that adhered to the fruit epicarp were probably removed during the washing step. Thus, fungal penetration into the fruit tissue had not occurred at this time. Consequently, fungus that was detected in fruit $24 \mathrm{~h}$ after inoculation had probably penetrated the tissue. In these laboratory inoculation and PCR detection studies, Bing cherry fruit was used. All fruit were symptomless at the time of sampling (up to 3 days after inoculation). Therefore, fungal infections at the time of sampling were either quiescent and nonvisible on the dark red fruit or were actively growing as incipient infections. In either case, fruit were still symptomless. In a recent study on the development of quiescent infections of sweet cherry fruit (1), it was found that, using between 9- and 12-h wetness periods, most quiescent infections developed after 4 to 6 days, whereas longer wetness periods favored the development of active decay. Thus, in the current study, quiescent infections that resulted from spore germination and penetration into fruit tissue without continued fungal growth were likely detected by PCR in fruit using 6- and 10-h wetness periods after inoculation. In the 18 -h wetness period, however, active decay of an incipient infection of the fungus was most likely detected.

Worldwide, M. laxa is found on all continents where stone fruit production occurs, whereas $M$. fructicola has only been reported from North, Central, and South America; Australia; New Zealand; and Japan. M. fructigena is mainly found in Europe and parts of Asia and South America (3). It is conceivable that molecular-detection methods could be developed for each of the three species for improved management practices or for regulation of imports for quarantine purposes. It is also possible that methods can be developed for the simultaneous detection of brown rot and gray mold, which are common diseases of sweet cherry and other stone fruit crops. Although this was not an objective of our research, in our primer evaluations, we identified primers that amplified DNA from both genera. These primers, however, produced only faint bands not acceptable in a detection assay.

In summary, the primers we developed for the detection of $M$. fructicola infections confirmed the presence of the brown rot pathogen in cherry fruit during very early stages of disease development when no visual symptoms were evident and in fruit with visible quiescent infections that were produced in the laboratory or naturally occurred in the field. The method is currently being adapted to be used on a field scale with proper sampling strategies. Ultimately, a molecular-detection method could facilitate risk assessments of naturally infected fruit and help in decisions for pre- and postharvest decay management strategies for sweet cherry in California. Molecular-detection techniques have facilitated diagnosis of many plant pathogens in the past $(9,24)$. A deficiency of these methods becomes obvious, however, when they are being used to estimate disease potential. Molecular-detection techniques cannot differentiate between viable and nonviable infections. As indicated in previous studies $(1,16,28)$, not all quiescent infections are viable and, thus, they will not result in active fruit decay. Thus, for estimating disease potential, risks may be easily overestimated. For an accurate risk assessment, these techniques will have to be correlated to actual disease levels under field conditions or be combined with a bioassay.

\section{ACKNOWLEDGMENTS}

We thank the California Cherry Board for financial support. We also thank R. J. Hartin for assisting in DNA sequencing.

\section{LITERATURE CITED}

1. Adaskaveg, J. E., Förster, H., and Thompson, D. F. Etiology of quiescent infections and detection of Monilinia fructicola and Botrytis cinerea in sweet cherry fruit. Plant Dis. In press.

2. Adaskaveg, J. E., and Ogawa, J. M. 1994. Penetration of iprodione into mesocarp fruit tissue and suppression of gray mold and brown rot of sweet cherries. Plant Dis. 78:293-296.

3. Batra, L. R. 1991. World Species of Monilinia (Fungi): Their Ecology, Biosystematics and Control. Mycologia Memoir No. 16. J. Cramer, Berlin, Germany. 
4. Biggs, A. R. 1995. Detection of latent infections in apple fruit with paraquat. Plant Dis. 79:1062-1067.

5. Carbone, I., and Kohn, L. M. 1993. Ribosomal DNA sequence divergence within internal transcribed spacer 1 of the Sclerotiniaceae. Mycologia 85:415-427.

6. Cerkauskas, R. F., and Sinclair, J. B. 1980. Use of paraquat to aid detection of fungi in soybean tissues. Phytopathology 70:1036-1038.

7. Dugan, F. M., and Roberts, R. G. 1994. Etiology of preharvest colonization of Bing cherry fruit by fungi. Phytopathology 84:1031-1036.

8. Faretra, F., Antonacci, E., and Pollastro, S. 1988. Sexual behaviour and mating system of Botryotinia fuckeliana, teleomorph of Botrytis cinerea. J. Gen. Microbiol. 134:2543-2550.

9. Förster, H., and Adaskaveg, J. E. 1998. Development of a molecular detection method for quiescent infections of sweet cherry fruit to estimate disease potential. (Abstr.) Phytopathology 88(suppl.):S29.

10. Free, S. J., Holtz, B. A., and Michailides, T. J. 1996. Mating behavior in field populations of Monilinia fructicola. Mycologia 88:208-211.

11. Fulton, C. E., and Brown, A. E. 1997. Use of SSU rDNA group-I intron to distinguish Monilinia fructicola from $M$. laxa and M. fructigena. FEMS Microbiol. Lett. 157:307-312.

12. Gindrat, D., and Pezet, R. 1994. Le paraquat, un outil pour la révélation rapide d'infections fongiques latentes et de champignons endophytes. J. Phytopathol. 141:86-98.

13. Harada, Y. 1977. Studies on the Japanese species of Monilinia (Sclerotiniaceae). Bull. Fac. Agric. Hirosaki Univ. 27:30-109.

14. Holst-Jensen, A., Kohn, L. M., Jakobsen, K. S., and Schumacher, T. 1997. Molecular phylogeny and evolution of Monilinia (Sclerotiniaceae) based on coding and non-coding rDNA sequences. Am. J. Bot. 84:686-701.

15. Holst-Jensen, A., Kohn, L. M., and Schumacher, T. 1997. Nuclear rDNA phylogeny of the Sclerotiniaceae. Mycologia 89:885-899.

16. Jenkins, P. T., and Reinganum, C. 1965. The occurrence of a quiescent infection of stone fruits caused by Sclerotinia fructicola (Wint.) Rehm. Aust. J. Agric. Res. 16:131-140.

17. Judelson, H. S. 1996. Genetic and physical variability at the mating type locus of the oomycete, Phytophthora infestans. Genetics 144:1005-1013.

18. Northover, J., and Cerkauskas, R. F. 1994. Detection and significance of symptomless latent infections of Monilinia fructicola in plums. Can. J. Plant Pathol. 16:30-36.
19. Ogawa, J. M., and English, H. 1991. Diseases of Temperate Zone Tree Fruit and Nut Crops. University of California, Div. of Agric. and Nat. Resources, Oakland, CA. Publ. No. 3345.

20. Ogawa, J. M., Manji, B. T., and Schraeder, W. R. 1975. Monilinia life cycle on sweet cherries and its control by overhead sprinkler fungicide applications. Plant Dis. Rep. 59:876-880.

21. Persing, D. H., Smith, T. F., Tenover, F. C., and White, T. J. 1993. Diagnostic Molecular Microbiology-Principles and Applications. American Society for Microbiology, Washington, DC.

22. Raeder, U., and Broda, P. 1985. Rapid preparation of DNA from filmentous fungi. Lett. Appl. Microbiol. 1:17-20.

23. Ribeiro, O. K. 1978. A Source Book of the Genus Phytophthora. J. Cramer, Vaduz, Liechtenstein.

24. Schots, A., Dewey, F. M., and Oliver, R. 1994. Modern Assays for Plant Pathogenic Fungi: Identification, Detection, and Quantification. CAB International, Oxford, United Kingdom.

25. Snyder, C. L., and Jones, A. L. 1999. Genetic variation between strains of Monilinia fructicola and Monilinia laxa isolated from cherries in Michigan. Can. J. Plant Pathol. 21:70-77.

26. Steiner, J. J., Poklemba, C. J., Fjellstrom, R. G., and Elliott, L. F. 1995 A rapid one-tube genomic DNA extraction process for PCR and RAPD analyses. Nucleic Acids Res. 23:2569-2570.

27. Thind, K. S., and Keitt, G. W. 1949. Studies on variability of Sclerotinia fructicola (Wint.) Rehm. Phytopathology 39:621-636.

28. Wade, G. C., and Cruickshank, R. H. 1992. The establishment and structure of latent infections with Monilinia fructicola on apricots. J. Phytopathol. 136:95-106.

29. White, T. J., Bruns, T., Lee, S., and Taylor, J. 1990. Amplification and direct sequencing of fungal ribosomal RNA genes for phylogenetics. Pages 315-322 in: PCR Protocols: A Guide to Methods and Applications. M. A. Innis, D. H. Gelfand, J. J. Sninsky, and T. J. White, eds. Academic Press, San Diego, CA.

30. Wilcox, W. F. 1990. Postinfection and antisporulant activities of selected fungicides in control of blossom blight of sour cherry caused by Monilinia fructicola. Plant Dis. 74:808-811.

31. Wittig, H. P. P., Johnson, K. B., and Pscheidt, J. W. 1997. Effect of epiphytic fungi on brown rot blossom blight and latent infections in sweet cherry. Plant Dis. 81:383-387. 